\title{
Yoksulluğun Ailedeki Sosyalleştirme Süreçlerine ve Çocuklardaki Bilişsel Gelişim ve Okul Başarısı Üzerine Etkisi
}

\section{Influence of Poverty on Socialization Processes in Family and Cognivite Development}

\section{Turhan ŞENGÖNÜL}

\author{
*Ege Üniversitesi, Eğitim Fakültesi, Temel Eğitim Bölümü, turhan. sengonul@ege. edu. tr
}

ORCID Numarası I ORCID Number : 0000-0003-4760-2204

\begin{abstract}
$\ddot{O Z Z}$
Bu makale yoksulluğun ve ekonomik güçlügün sosyalleştirme süreçleri ve çocukların ve ergenlerin bilişsel gelişmesi, bilişsel becerileri ya da okul başarısı üzerindeki etkisini ele almaktadır. Ekonomik güçlük ile ilgili aile stres modeli, yoksulluk ve ekonomik güçlüğün ekonomik baskıya yol açtığını ve ekonomik baskı yüksek olduğunda annelerin-babaların moral bozukluğu, endişe, kızgınlık ve yabancılaşma gibi duyguları hissederek üzüntüyü yaşama yönünde artan bir riskte olduğunu ileri sürmektedir. Yoksulluk ve ekonomik güçlük, annelerin-babaların onların iyi olmasına yarar ve katkı sağlamak için çocukları ile etkileșme ve onları sosyalleștirme yeteneğini azaltmaktadır. Düşük gelir ve yoksulluk, annelerin-babaların duygularını, davranışlarını ve ilişkilerini kötü olarak etkilemekte ve annelerin-babaların sıcaklığını, duyarlılığını ve gözetimini azaltarak ve ailede anne-baba-çocuk ilişkilerinde ve etkileşimlerinde çatışmayı, ilgi göstermeyen ve tutarsız sosyalleştirme uygulamalarını ve sert ceza kullanımını arttırarak ailenin işlevine, işlerliğine ve sosyalleştirme süreçlerine zarar vermektedir. Araştırmacılar yoksul ve morali bozuk annelerin-babaların okumada ve verimli, bol, zengin konuşmada çocuklarla meşgul olma ya da ev ödevinde çocuklara yardım etme gibi çocuklarında bilişsel becerilere ve okul başarısına katkı yapan bilişsel olarak teşvik eden çocuk yetiştirme uygulamaları ve etkinliklerle aktif olarak daha az meşgul olduklarına işaret etmektedir. Ekonomik güçlükle ilgili aile stres modeli, aileleri yoksulluğu ve ekonomik güçlüğü yaşadıklarında çocukların ve ergenlerin düşük zeka puanları, düşük bilişsel beceriler, düşük eğitimsel kazanım, düşük okul başarısı gibi olumsuz sonuçlara sahip olma yönünde artan riskte olduğunu ileri sürmektedir.
\end{abstract}

Anahtar Sözcükler:Yoksulluk, aile stresi, sosyalleştirme süreçleri, düşük bilişsel gelişme, düşük okul başarısı.

\begin{abstract}
This article addresses influence of poverty and economic hardship on socialization processes and cognivite development, cognivite skills or school achievement of children and adolescents. The family stress model of economic hardship suggests that poverty and economic hardship lead to economic pressure and parentsare at increased riskfor experiencing emotionally distressby feelingemotions such as depression, anxiety, anger, and alienation when economic pressure is high. Poverty and economic hardship reduce parents' ability to interact with and socialize children in order to benefit and contribute to their well-being. Low income and poverty influence adversely emotions, behaviors, and relationships of parents and undermine family functioning and socialization processes by reducing warmth, responsiveness, support and supervision of parents and by increasing conflict and uninvolved and inconsistent socialization practices and the use of harsh punishments in parent-child relationships and interactions in family. Researchers indicate that poor and depressed parents actively less engage in cognitively stimulating parenting practices and activities that contribute to cognitive skills and school achievement in their children such as engaging children in reading and rich conversation or helping children with homework. The family stress model of economic hardship assert that children and adolescents are at increased for having negative outcomes such as low IQ scores, low cognivite skills, low educational attainment, low school success when their families experience poverty and economic hardship.
\end{abstract}

Keywords: Poverty, family stress, socialization processes, low cognivite development, low school achievement. 


\section{Giriş}

Ekonomik güçlükle ilgili aile stres modelinin temelleri, 1930'lu yıllarda kapitalizminbüyük bunalımının toplumlarda yol açtığı sonuçlarla ilişkili toplanan verilere kadar uzanmaktadır. Kapitalizmin büyük bunalımının yarattığ 1 sonuçları inceleyen araştırmalar, toplumdaki yoğun ekonomik güçlüklerin ailelerin yaşamlarını olumsuz biçimde etkilediğini, ailelerin işlevini bozduğunu ve ailelerdeki sosyalleştirme süreçlerine zarar verdiğini ortaya çıkarmıştır (Conger, 2005). Aile stres teorisine göreekonomik güçlükler ailelerde ekonomik baskıya yol açmaktadır. Düşük gelir ya da yoksulluk, maddi kaynakların azalması,ekonomik isteklerin artması ve bu istekleri karşılayamama, servetin varlığınave gelire göre daha yüksek düzeyde borçlar, çalışma ve iş yaşamındaki istikrarsızlık gibi öğeler, ailelerdeki ekonomik güçlüğün göstergeleri olarak nitelendirilmektedir. Yoksul aileler, yeterli ve düzenli beslenme, giyinme, barınma, sağlık hizmeti alma gibi temel ve zorunlu gereksinimleri karşılayamama, yaşamak için gerekli olan elektrik, su, doğal gaz tüketiminden kaynaklanan faturaları ödeyememe, ekonomik harcama gerektiren belirli amaçlarına ulaşamama gibi risklerle karşılaşmaktadır. Ekonomik güçlükler, ailelerde baskı yaratmakta ve ailelerin işlerliğini, işlevlerini bozmakta ve ailelerdeki sosyalleştirme süreçlerini olumsuz biçimde etkilemektedir (Conger, 2005). Aile stres teorisine göre ailelerde ekonomik güçlük ve baskı yüksek olduğunda annelerin-babaların moralleri bozulmakta, onlar üzülmekte, endişe, kızgınlık, öfke duymakta, yabancılaşma ve uzaklaşma eğilimi göstermektedir. Bu koşullar, ailelerde madde kullanımı ve anti-sosyal davranış risklerini arttırmaktadır. Yoksulluğun yol açığı bu tür duygusal ve davranışsal problemler,ailelerdekiçatışmayı artırmakta,s ıcaklığı, sevgiyi ve desteği azaltmakta ve böyle bir ortam, annelerin-babaların çocuklarının eğitimiyle ve sosyalleştirilmesiyle meşgul olma kapasitesini zayıflatmaktadır. Yoksulluk ve ekonomik güçlükler nedeniylemoralleri bozulan, üzülen, endişe, kızgınlık, öfke duyan anneler-babalar, çocuklarına sıcaklığı ve sevgiyi daha az gösterebilmekte, çocuklarının günlük etkinlikleriyle daha az meşgul olabilmekte ve disiplinle ilgili uygulamalarda çocuklarına daha çabuk kızan, sinirli, sert ve tutarsız biçimlerde davranabilmektedir. Annelerin-babaların bu tür tutumları ve davranışları, çocuklarının eğitimlerini ve sosyalleştirilmelerini aksatabilmektedir. Annelerin-babaların eğitimi ve ilgisi, çocuklarınfiziksel, bilişsel, duygusal, davranışsal gelişiminde ve onların iyi olmasında önemli bir rol oynamaktadır. Aileler üzerinde yarattı̆gı olumsuz etkilerle yoksulluk ve ekonomik güçlükler, annelerin-babaların çocuklarını eğitme ve sosyalleştirme süreçlerini tehdit ettiğinde çocukların olumlu ve başarılı gelişimi riske, tehlikeye girmektedir(Conger ve Conger, 2002; Conger, Wallace, Sun, Simons, McLoyd ve Brody, 2002). Ekonomik güçlüğü yaşayan yoksul ailelerdeki çocuklarda daha düşük bilişsel ve sosyal yeteneklere vedaha düşük okul başarısına sahip olma riski daha büyük görünmekte ve bu çocukların annelerine-babalarına daha az sevgi ve daha az bağl1lık gösterme eğilimi ile çocuklarda moral bozukluğu ve endişe biçiminde içselleşen problemlerin ve saldırganlık ve anti-sosyal davranış biçimindedışa yansıyan problemlerinartma riski büyük bir olasılık olarak durmaktadır (Conger ve Donnellan, 2007). 


\section{Yoksul ya da Alt Sosyoekonomik Statüdeki Annelerin-Babaların İş Koşulları ve Değerleri}

Yoksul ya da işçi sınıfındaki anneler-babalar,genellikle aletlerin ve makinelerin yer aldığı koşullarda çalışmaktadır. İşçi sınıfı anneler-babalar, işverenler, mühendisler, teknisyenler, ustabaşılar tarafindan daha çok doğrudan gözetlenmekte, denetlenmekte ve çalışmayı ve işibağımsız olarak yürütmemekte ve yönetmemektedir. Mühendis, mimar, doktor, avukat gibiorta sosyoekonomik statüde yer aldığı kabul edilen profesyonel meslek sahiplerinin ve yöneticilerin çalışma yaşamında konumları, görevleri, işleri çoğunlukladerin ve etkili biçimde düşünmeyi, yaratıcılığı, kendini yönetmeyi ve diğer insanları yönetmeyi gerektirirken, yoksul ya da işçi konumundaki bireyler, toplumda prestiji daha düşük olarak görülen işlerde çalışmakta,iş yaşamında işyerinin kurallarına uymakta, işveren ya da kendilerinden daha üst statüde yer alan profesyonel meslek sahipleri ve yöneticiler tarafından gözetlenmekte ve onlar çok ve karmaşık düşünmeyi ve yaratıcılığ 1 gerektirmeyen, tekrar eden, rutin ve standart işleri ya da görevleri yapmaktadır(Kohn, 1995). Annelerin-babaların işleri ve sahip olduğu meslekleri, onların değerlerini, amaçlarını, davranışlarını ve sosyalleştirme uygulamalarını etkilemektedir. Alt sosyoekonomik statüdeki anne-baba ile orta sosyoekonomik statüdeki annebaba,kişilik ve yaşam yönelimi bakımından farklılaşmakta ve yaşamda çocukları için koydukları amaçlar ve öncelikler değişmektedir. İşçi sınıfındaki anneler-babalar, çocuklarını sosyalleştirme ve eğitme sürecinde genellikle uyuma ve itaate daha çok değer verirken,çocuklarında entelektüel merakı geliştirmeyi çok düşünmemekte ya da entelektüel merakı ilerletmede başarılı bir rol oynayamamakta, evde çocukların bilişsel gelişimine hizmet edenentelektüel etkinlikleri daha az yapmakta ve bu konuda yeterli düzeyde rol model davranışlar göstermemektedir. Bu anneler-babalar, çocuklarının eğitimle ve derslerle meşgul olmasını yeterli biçimde sağlayamamaktadır (Kohn, 1995). Senechal ve LeFevre (2002) yoksul ve düşük ekonomik koşullarda yaşayan annelerin-babalarındaha çok emredici tutumlarla iletişime girdiklerini, bu ailelerde çocukların karmaşık düşünmeyle meşgul olmasının beklenmediğini ve teşvik edilmediğini ileri sürmektedir. Lareau (2003) orta sosyoekonomik statüdeki anneler-babalar sosyalleştirme sürecinde çocuklarıylagörüşmeyi,müzakere yapmayı,sonuca bağlamayıve tümevarımsal akıl yürütmeyidaha çokkullanırken, yoksul ya da işçi sınıfı annelerin-babaların çocuklarına sözle anlatma, açıklama ve akıl yürütme yollarını ve yöntemlerini daha az kullandıklarını, bunun yerine emirleri daha çok verdiklerini vurgulamaktadır. Hoffman (2003) ve Hoff, Laursen ve Tardif'e (2002) göre alt sosyoekonomik statüdeki anneler-babalar, sosyalleştirme süreçlerinde çocuklarına daha sert ve katı bir yaklaşımla otoriteryan tutum ve davranışları daha çok göstermekte, fiziksel cezayı daha çok kullanmakta ve çocukların diğerlerine yönelttikleri davranışların olumlu ve yararlı sonuçları ya da olumsuz, zararlı ve kötü sonuçları hakkında çocuklarıyla daha az konuşmakta, onlara daha az açıklama yapmakta ve onlar için tümevarımsal akıl yürütmeyi daha az kullanmaktadır. Conger ve Dogan (2007) alt sosyoekonomik statüdeki annelerin-babaların sosyalleştirme süreçlerinde çocuklarının yaptıkları davranışın altında yatan nedenlerini aramaktan çok, gerçekleşen ve görünen davranışın kendisine odaklandıklarına ve hemen fiziksel cezaya başvurabildiklerine işaret etmektedir. Menaghan ve Parcel (1991) ise annelerin-babaların sahip oldukları işlerin ve mesleklerin çocukların sosyalleştirilmesinde rol oynadığını, bilişsel becerileri daha düşük düzeyde olan annelerin-babaların çocuklarını bilişsel olarak daha az teşvik ettiklerini tartışmaktadır. 


\section{Ekonomik Güçlükle İlgili Aile Stres Modelini Destekleyen Araştırma Bulguları ve Tartışmalar}

Araştırmacılar ekonomik güçlükle ilgili aile stres modelini destekleyen bulguları ortaya çıkarmışlardır. Yoksulluğa maruz kalma, olumsuz yaşam olaylarını arttırmış, anne-baba-çocuk ilişkilerinde ve etkileşimlerinde daha çok stres yaratmış ve çocuk yetiştirmenin olumlu uygulamalarını azaltmıştır (Duncan ve Brooks-Gunn, 1997; Guo ve Harris, 2000). Alt sosyoekonomik statünün göstergeleri olarak düşük gelir düzeyi ve yoksulluk,ailedeki sosyalleştirme sürecine zarar vermiş, annelerin-babaların çocukları yönündeki sıcak, sevgi dolu ve duyarlı uygulamalarını ve çocukların duygusal, psikolojik, sosyal ve bilişsel gelişimine hizmet eden sosyalleştirme çabalarını azaltmıştır. Düşük gelir, yoksulluk ve işsizlik gibi kötü koşullar, annelerin-babaların sosyalleştirme sürecindeki sıcaklığını, duyarlılığını ve denetimini azaltmış, sert ceza kullanımını ve tutarsız disiplin uygulamalarını arttırmıştır (Smith, Brooks-Gunn ve Klebanov, 1997). Düşük gelir düzeyi ve yoksulluk,çocukların bilişsel gelişimini, bilişsel becerilerini ya da akademik başarısını olumsuz biçimde etkilemiştir. Çocuklardaki ve ergenlerdeki düşük eğitimsel kazanım, düşük zeka puanları, düşük akademik başarı ile ailelerdeki düşük gelir düzeyi ve yoksulluk arasında güçlü bir ilişki bulunmuştur(Duncan, Brooks Gunn ve Klebanov, 1994; Şirin, 2005). Düşük gelirli ve yoksul aileler, çocuklarının yeterli ve düzenli beslenme, barınma, giyinme, sağlik hizmeti gibi temel ve zorunlu gereksinimlerini karşılamada zorluklar ve sıkıntılar yaşamışlardır. Bu ailelerden gelen çocuklar yaşamlarını daha kötü koşullarda sürdürmüşler, daha az yemek tüketmişler, bilişsel olarak teşvik eden oyuncaklara daha az sahip olmuşlar ve çocuklar bilişsel olarak teşvik eden etkinliklerle daha az meşgul olmuşlardır. Diğer anneler-babalar ile karşılaştırıldığında eğitimi ve gelir düzeyi düşük yoksul anneler-babalar, görece biçimde insan sermayesi olarak daha az bilgi ve beceriye ve ekonomik sermaye olarak daha az gelire ve sosyal sermaye olarak mesleğin sağladığı sosyal çevreye ve iletişim becerilerine daha az sahip olduğu için çocukları ile daha az zaman geçirmişler ve çocuklarına daha az sosyal sermaye sağlamışlardır (Mayer, 1997). McLoyd (1990)araştırmasında düşük sosyoekonomik statüdeki annelerin-babaların, sosyalleştirme sürecinde daha çok olumsuz ve sert uygulamalara başvurduklarını ve onların daha düşük enerji ve daha düşük sosyal destek düzeylerine sahip olduklarını, daha çok moral bozukluğu, kızgınlık ve endişe gibi olumsuz duyguları yaşadıklarını, iş yaşamlarında daha çok sıkıntı ve üzüntü duyduklarını ve bu koşullardan dolayı annelerin-babaların çocuklarına daha az sıcak ve daha az duyarlı davrandıklarını ve onları daha az kontrol ettiklerini ya da daha az izlediklerini bulmuştur. Düşük ücret, yoksulluk, stresli işler, annelerde-babalarda moral bozukluğuna, strese ve endişeye yol açmış, annelerin-babaların çocuklarını sosyalleştirme sürecinde sıcak, destekleyici ve tutarlı bir aile çevresi sağlama kapasitesini azaltmıştır. Yoksul anneler-babalar, onların okulların sunduğu öğrenme fırsatlarıyla ilgilenmesi ve meşgul olması için ve bilişsel olarak teşvik eden deneyimleri kazanması için çocuklarını motive etmede, güdülendirmede ve teşvik etmede güçlükler yaşamışlardır (McLoyd, 1998; Elder, 1999).

Araştırmalar düşük gelir, yoksulluk ve annenin-babanın düşük eğitim düzeyi ile çocuklardaki daha yavaş bilişsel gelişme, düşük okul performansı ve düşük zeka puanları arasındaki karş1lıklı ilişkiye işaret etmişlerdir (Halle, Kurtz-Costes ve Mahoney, 1997). Araştırma bulguları, ailedeki düşük gelirin ve yoksulluğun çocukların bilişsel gelişiminde, bilişsel kazanımlarında, okuma ve matematik sonuçlarında ve okul başarısında güçlü bir biçimde olumsuz rol oynadığını 
ve ilk çocukluktaki daha zayıf bilişsel gelişim ve becerilerle ilişkili olduğunu göstermiştir. Diğer dönemlerdeki yoksulluğa maruz kalma durumuyla karşılaştırıldığında ilk çocuklukta yoksulluğa maruz kalma, çocukların bilişsel gelişimini, bilişsel becerilerini ve akademik başarısını daha çok olumsuz bir biçimde etkilemiştir. Ailelerin düşük gelir ya da yoksulluk düzeyi ve uzun yoksulluk süresi gibi olumsuz koşulları, 5 yaşından daha küçük çocukların bilişsel gelişiminde ve okuldaki öğrenmeye hazırlığında çok belirgin bir biçimde rol oynamıştır (Anand ve Lea, 2011; Burney ve Beilke, 2008; Dahl ve Lochner 2005; Haveman ve Wolfe, 1995; Korenman, Miller ve Sjaastad, 1995;Smith, Brooks-Gunn ve Klebanov, 1997). Orta ve üst sosyoekonomik statüdeki ailelerin çocukları ile karşılaştırıldığında alt sosyoekonomik statüdeki annelerin-babaların çocukları okul öncesi dönemi ana sınıfına geçişte okuma ve matematik testlerinden anlamlı biçimde daha düşük puan almışlardır (Baker, Cameron, RimmKaufman ve Grissmer, 2012; Crosnoe ve Cooper, 2010). Lee ve Burkam (2002) daha düşük sosyoekonomik statüdeki ailelerden gelen çocukların orta ve üst sosyoekonomik statüdeki ailelerden gelen akranlarına göre daha düşük okuma ve matematik becerileri ile ana sınıfına girdiklerini, okula devam ettiklerini ve bu dezavantajların okul yıllarında sürdüğünü bulmuşlardır. Araştırmalarında Duncan ve Seymour (2000) alt sosyoekonomik statünün göstergesi olarak yoksul kesimlerden gelen çocukların okulda harf tanıma ve temel okuryazarlık becerilerinde akranlarının gerisinde kaldıklarını bulmuşlardır. Orta ya da üst sosyoekonomik kesimlerden gelen akranlarıyla karşılaştırıldığında alt sosyoekonomik kesimlerden gelen çocuklar, 3 yaşa kadar daha düşük zeka puanlarına sahip olmuşlardır(Klebanov, Brooks-Gunn, McCarton ve McCormick, 1998). Yoksulluğundan dolayı morali bozulan ve üzüntü yaşayan anneler-babalar, çocuklarıyla sözlü iletişimleri ve etkileşimleri daha az gerçekleştirmişler, onlara dikkatli ve duyarlı biçimlerdedaha az davranmışlar ve sevgi dolu, sıcak ve teşvik eden davranışları daha az göstermişlerdir. Bu tür davranışlar sergileyen annelerin-babaların çocukları, ilk çocuklukta bilişsel beceri testlerinde daha düşük puanlar almışlar ve orta çocuklukta karmaşı görevlerde dikkatlerini odaklamakta ve yoğunlaştırmakta güçlük çekmişlerdir (Gelfand ve Teti, 1990; Lovejoy, Graczyk, O'Hare ve Neuman, 2000). Düşük sosyoekonomik statüdeki annelerin çocuklarını sert biçimde kontrol etme eğilimleri ve çocuklarından itaat etmelerini istemesi gibi otoriteryan tutum ve davranışları ile yoksulluktan kaynaklanan moral bozukluğu ve endişesi yönündeki değişkenlerle4 yaş çocuklarında daha düşük zeka puanları arasında bir ilişki gözlenmiş(Sameroff, Seifer, Barocas, Zax ve Greenspan, 1987)ve bu çocuklarda ilk ergenlik döneminde daha yavaş bir bilişsel gelişme görülmüştür(Sameroff, Seifer, Baldwin, A. ve Baldwin, C. , 1993). Orta ve üst sosyoekonomik statüdeki ailelerin çocukları ile karşılaştırıldığında refah ve sosyal devletin sunduğu ekonomik ve sosyal yardımlara ve desteklere muhtaç olan yoksul ve işsiz kesimlerden gelen okul-çağı çocukları, sözel beceriler testinde daha düşük puanlar almışlardır (Sampson, Sharkey ve Raudenbush, 2008). Daha düşük eğitim, daha az prestijli meslek ve daha düşük gelir düzeyleriyle alt sosyoekonomik statüdeki annelerin-babaların genellikle sosyalleştirme sürecinde çocukları için sert ya da olumsuz uygulamaları ile çocuklardaki ve ergenlerdeki daha düşük bilişsel yetenek ve uyumsuz davranışlar arasında anlamlı bir ilişki olduğu görünmüştür (Bradley ve Corwyn, 2002; Luster, Rhoades ve Haas, 1989). Yeung ve meslektaşları (2002) ulusal olarak temsil edici bir nitelikte olan ve sosyoekonomik statü ve aile yapısı, oturulan yer ve etnisite bakımından oldukça farklı ve çeşitli olan bir örneklemle 3 ile 5 yaş arasında 753 okul öncesi ana sınıfı erkek ve kız öğrenci üzerinde yürüttüğü araştırmada annelerin çocukları için 
öğrenme etkinlikleri yapması ve evde bilişsel olarak teşvik eden materyalleri ve deneyimleri sağlaması yoluyla aile geliri ile çocuklardaki ilk okuryazarlık becerileri arasındaki ilişkiye aracılık ettiğini ortaya çıkarmıştır. Araştırma, ekonomik güçlükle ilgili aile stres modelini destekleyen bulgulara işaret etmiştir. Yoksulluğun ve ekonomik güçlüğün yol açtığ stres süreçleri,annelerin-babaların çocukları için gösterdiği sıcaklığı ve sevgiyi azaltmış ve böyle bir ortamda çocukları sosyalleştirme süreçlerinin ve çocuk yetiştirme davranışlarının çocuklardaki daha düşük bilişsel yeteneklerle ve yüksek oranda problem davranışlarla ilişkili olduğu görünmüş̧ür. Yoksulluktan dolayı moralleri bozuk ve üzüntülü olduğunda anneler-babalar, çocuklarına okuma, daha çok ve verimli bir biçimde konuşma, ev ödevinde yardım etme gibi çocuklarının bilişsel gelişimine, bilişsel becerilerine ve okul başarısına katkı yapan etkinliklerle daha az meşgul olmuşlardır. Araştırmacılar düşük gelir ya da yoksulluk ile çocukların harfsözcük puanlarının düşüklüğü arasında karşılıklı bir ilişki olduğunu bulmuşlardır. Reardon (2013) alt sosyoekonomik statüdeki ailelerin çocukları ile orta ve üst sosyoekonomik statüdeki ailelerin çocukları arasındaki bilişsel gelişme ya da akademik başarı farklılıklarının okula girişte kendini gösterdiğini belirtmiştir. Entwisle ve Alexander (1993) başlangıçtaki sosyoekonomik kültürel eşitsizliklerin zamanla okuldaki akademik başarı farklılıklarını oldukça arttırdığını vurgulamışlardır. Dyson, Hett ve Blair (2003)ailedeki yoksulluğun bilişsel gelişme ve akademik başarı üzerindeki etkisinin ilk çocuklukta başladığına ve okul yılları boyunca sürdüğüne işaret ederek, yoksul ya da alt sosyoekonomik statüdeki ailelerden gelen çocukların okuryazarlığı kavramada ve okuma anlama becerilerinde daha düşük düzeylerde olduklarını ve bu çocukların harf tanıma ve anlama olarak okur-yazarlıkla ilişkili daha düşük beceri düzeyleri ile okula girdiklerini ileri sürmüşlerdir. Burchinal, Vernon-Feagans, Cox ve Investigators (2008) yoksulluk ile çocuklardaki okuma ve matematik başarısı arasındaki olumsuz bir ilişkiye dikkat çekerek, annelerin çocuklar ile iletişim kurması, çocukları için okuması ve evde öğrenme etkinlikleri ile meşgul olması gibi öğelerin çocukların bilişsel gelişiminde rol oynadığını vurgulamışlardır. Votruba-Drzal, (2003) ise orta ve üst sosyoekonomik statüdeki annelere göre yoksul annelerin çocuklarına okumayı, harfleri, sayıları ve şekilleri doğrudan öğretmek için daha az çaba gösterdiklerini ileri sürmüştür. Ekonomik güçlükle ilgili aile stres modeli temelindearaştırmacılar, düşük gelir düzeyinin ve yoksulluğun annelerde-babalarda stres, moral bozukluğu, kızgınlık ve endişe gibi olumsuz duygulara neden olabilmesi ve annelerin-babaların psikolojik ve duygusal olarak iyi-olmasını ve çocuk yetiştirme uygulamalarını olumsuz etkilemesi ve bu durumların ise çocuklarda ve ergenlerde daha düşük bilişsel yeteneğe ve uyumsuz davranışlara yol açabilmesi bakımından aile gelir düzeyinin rolünü tartışmışlardır. Ekonomik güçlükle ilgili aile stres modelinde önemli bir öğe olarak çocuk yetiştirme davranışları, düşük gelir düzeyi ya da yoksulluk ile çocuklardaki bilişsel gelişme ve beceriler arasındaki ilişkiye aracılık etmiştir. Çocuk yetiştirme uygulamaları, ilk yıllardaki davranış problemleri kadar çocuklardaki bilişsel gelişimi belirgin bir biçimde etkilemiştir (Collins, Maccoby, Steinberg, Hetherington ve Bornstein, 2000).

Ergenler üzerinde yapılan araştırmalar, ekonomik güçlükle ilgili aile stres modeliyle tutarlı bulgulara ulaşmışlardır. Yedinci sınıf öğrencileri üzerinde yürüttüğü araştırmalarda annelerinbabaların ekonomik güçlüklere, baskılara gösterdiği tepkiler, öğrencilerin problemleri ve onların okul performansı arasındaki ilişkileri inceleyen Conger, Wallace, Sun, Simons, McLoyd ve Brody (2002)ekonomik güçlükle ilgili aile stres modelini destekleyenbulguları elde 
etmişlerdir. Araştırmacılar, yoksulluğun ailelerin günlük yaşamlarında streslerini ve gerilimlerini arttırdığını, sosyalleştirme sürecinde annelerin-babaların çocuklarına sevgi dolu ve sicak davranma ve onlar için bilişsel olarak teşvik eden uygulamalarla meşgul olma kapasitelerini azalttığını bulmuşlardır. Sonuç olarak ekonomik güçlük, öğrencilerin okul performansını olumsuz biçimde etkilemiştir. Araştırmacılar, düşük gelir düzeyinin ve yoksulluğun, annelerde-babalarda strese, moral bozukluğuna, endişeye ve kızgınlığa yol açtı̆̆ınıve psikolojik, duygusal olarak iyi-olmayı olumsuz etkilediğini ve böylece sosyalleştirme sürecinde anne-baba çocuk ilişkilerinde ve etkileşimlerinde annelerin-babaların çocukları yönündeki sıcaklığını, duyarlılığını, desteğini azalttığını ve annelerin-babaların çocuk yetiştirmede sert yaklaşımlara, cezaya ve tutarsız uygulamalara başvurmasını arttırdığını, böyle bir aile ortamının iseekonomik gelir ile çocuklardaki bilişsel gelişme arasındaki ilişkiye aracılık ettiğini vurgulamışlardır. Conger, R. D. , Conger, K. J. , Elder , Lorenz, Simons, ve Whitbeck $(1992$; 1993) ilk olarakannelerin ve babaların birlikte yaşadığı yoksul köylü beyaz ailelerden gelen, yedincisınıfta öğrenim gören 205 erkeköğrenci ve ikinci olarakyine yoksul köylü beyazailelerden gelen yedinci sınıfta eğitimini sürdüren 220 kız öğrenci üzerinde yaptıkları iki araştırmada ekonomik güçlükle ilgili aile stres modelini açık bir biçimde test etmişler ve aile stres modelinin ileri sürdüğü savları doğrulamışlardır. Araştırmacılar başka bir çalışmada \%39 oranı, biyolojik anneleri ve babaları ile, \% 33'ü üvey anneleri-babaları ile ve \% 28 'si sadece anneleri ve büyükanneleri ile birlikte yaşayan ve çok yoksul ailelerden ekonomik gelir düzeyi yüksek ailelere kadar değişik sosyoekonomik statüdeki ailelerden gelen 422 kız ve erkek beşinci sınıf öğrencisini incelemişlerdir. Bakıcı olarak biyolojik annelerin ve babaların, üvey annelerin ve babaların vesadece annelerin ve büyükannelerin yer aldığı ailelerde de yoksulluğa ve ekonomik güçlüğe tepki olarak moral bozukluğu, üzüntü, stres, gerilim, endişe gözlenmiştir. Böyle bir ortam, ailedeki sıcaklığı, sevgiyi azaltmış veannelerinbabalarınçatışmasını, kızgınlığını ve sertya da tutarsız disiplin uygulamalarını arttırmış ve çocuklarının sosyalleştirilme süreçlerini olumsuz etkilemiştir (Conger vd. , 2002). Araştırmalar ailelerdeki ekonomik güçlüğün,ekonomikbaskının ve psikolojik üzüntünün yol açtığı ilişkileri ortaya çıkarmışlardır. Annelerin ve babaların üzüntüsü doğrudan ailelerdeki sıcaklığı, sevgiyi azaltarak ve sert ya da tutarsız disiplini arttırarak çocukların sosyalleştirilme süreçlerini bozmuştur. Araştırma bulguları bozulan sosyalleştirme süreçleri ile çocuklardaki ve ergenlerdekidaha düşük düzeylerde sosyal yetenekler ve daha çok davranış problemleri gibi olumsuz sonuçlar arasında anlamlı bir ilişkiyi göstermiştir(Conger, 2005). Diğer bir araştırmada Mistry, Vandewater, Huston ve McLoyd (2002) yoksul kente yaşayan,\%83 oranında sadece annenin ya dababanın yer aldığı çoğu etnik azınlıktaki \% 57 oranında Afrikalı Amerikan,\% 28 oranında İspanyol ailelerden gelen ve yaşları 5 ile 12 arasında değişen 419 öğrenciyi incelemişlerdir. Yarattığı ekonomik baskılarla yoksulluğun ve ekonomik güçlüğün çocukların sosyalleştirilme süreçlerini ya da çocuk yetiştirme davranışlarını nasıl etkilediğini ele alanaraştırmacılar, yoksulluğun annelerde-babalarda yol açtığı moral bozukluğunun ve üzüntünün ailedeki ekonomik problemler ile sadece annenin ya da babanın yer aldığ 1 ailelerde çocuk yetiştirme süreçlerinin bozulması arasındaki ilişkiye aracılık ettiğini bulmuşlardır. Ailelerdeki ekonomik güçlük,çocukların sosyalleştirilmesi sürecini olumsuz bir biçimde etkilemiştir. Düşük gelir düzeyi ve onun doğal bir sonucu olarak hissedilen ekonomik bask1, annelerin-babaların psikolojik, duygusal olarak iyi olma durumunu kötü bir biçimde etkilemesi yoluyla sosyalleştirme ve çocuk yetiştirme süreçlerinde önemli bir rol oynamıştır. Morali bozuk 
ve üzüntülü anneler-babalar, çocukları ile etkileşimlerinde daha az etkili ve daha az becerikli olduklarını bildirmişlerdir. $\mathrm{Bu}$ annelerin-babaların çocukları ile etkileşimlerinde daha az şefkatli, daha az sevgi dolu oldukları gözlenmiştir. Finlandiya' da hem annenin hem babanın yer aldığ 1 ailelerden gelen 527 erken-ergen erkekler ve kılar üzerine yapılan bir araştırmada Solantaus ve Punamaki (2004) ise yine benzer biçimde ekonomik güçlükle ilgili aile stres modelini destekleyen bulgulara ulaşmışlardır. Yoksulluktan dolayı annelerin-babaların yaşadığı moral bozukluğu ve üzüntü, anneler ve babalar arasında çatışmayı arttırmış ve bu çatışma çocukların sosyalleştirilmesi süreçlerine ve çocuk yetiştirme davranışlarına zarar vermiş, annelerin-babaların sıcaklığını, sevgisini azaltmış ve onların çocuklarına daha çok ceza uygulamasını arttırmıştır. Bulgular, yoksulluğun ve ekonomik güçlüğün annelerdebabalardayarattığı ekonomik baskılar, moral bozukluğu ve üzüntüler ve kötüleşen, bozulan aile ilişkileri yoluyla çocukların riskte olduğunu ileri sürenaile stres modeli ile oldukça tutarlı görünmüştür. Başka bir araştırmada ise kentte outran ailelerden Avrupalı Amerikan kökenli 111 ve Meksikalı Amerikan kökenli 167 beşinci sınıf öğrencisi örneklem olarak seçilmiş ve incelenmiştir. $\mathrm{Bu}$ araştırma da ekonomik güçlükle ilgili aile stres modelini destekleyen nitelikte bulguları ortaya çıkarmıştır. Annelerin-babaların moral bozukluğu, üzüntüsü ve endişesi gibi değişkenler, çocuk yetiştirmedeki olumlu davranışlarla olumsuz bir biçimde ilişkili görünmüştür. Yoksulluk, ekonomik güçlük ile çocukların sosyalleştirme süreçlerindeki ya da çocuk yetiştirmedeki olumsuz uygulamalar arasındaki ilişkilere aracılık etmiştir (Parke, Coltrane, Duffy, Buriel, Dennis ve Powers, 2004). Diğer bir araştırmadaCostello, Compton, Keeler ve Angold (2003)yoksul ailelerdeki gelir artışının etkisini incelemişlerdir. Araştırmada elde edilen bulgulara göre Hintli Amerikan toplulukta birkaç ailenin gazino işleterek gelir düzeylerini yükseltmesi ve böylece yoksulluğun dişına hareket etmesiyle bu ailelerdeki çocukların ekonomik durumları iyileştiği gibi psikiyatrik rahatsızlıkları daanlamlı bir biçimde azalmıştır. Gelir düzeyinin artması, ailelerde çocukları sosyalleştirme süreçlerinde ya da çocuk yetiştirmede görülen problemleri ve çocuklarda dışa yansıyan problemleri azaltmıştır. Sosyalleştirme ya daçocuk yetiştirme sürecindeki artan olumlu ve etkili davranışlar, aile gelir düzeyinin yükselmesi ile çocuğun iyi olması arasındaki ilişkiye aracılık etme yoluyla bu ilişkiyi açıklamıştır. Aile gelirindeki artışlar, annelerin-babaların yaşadığı ekonomik baskıları ve psikolojik üzüntüleri azaltmış ve sosyalleştirme ya daçocuk yetiştirmesüreçlerini iyileştirmiştir. Yoksul ailelerde geliryükseldiğinde ve yoksulluğun dişına hareket ettiklerinde ailelerdeki bireyler,kendilerinipsikolojik olarak iyi hissetmişler, çocukların ve ergenlerin fiziksel, sosyal, psikolojik ve bilişsel gelişimi olumlu bir biçimde etkilenmiştir. Aile gelirindeki iyileşmeler, aile stres modelinin savlarını doğrulayan sonuçları ortaya çıkarmıştır (Gennetian ve Miller, 2002; Huston ve Aronson, 2005; Leventhal ve Brooks-Gunn, 2003). Boylamsal araştırmasındaStrohschein (2005)aile gelirindeki artışın çocuklarda moral bozukluğunu ve antisosyal davranışları azalttığını bulmuştur. Yoksulluk ve özellikle derin ve yoğun yoksulluk, ailelerin işlerliğini, işlevlerini bozmuş, çocuklardaki bilişsel gelişimi engelleyebilmiş ve davranış problemlerini arttırmıştır.

Tarım ve köy toplumunda ve kent toplumunda ailelerdeki sosyalleştirme süreçlerini ele alan Kağıtçıbaşı ve meslektaşları, Türkiye'de 1975 yılında ulusal düzeyde temsil edici,2305 kişiyi içeren bir örneklemle ve 2003 yılında Batı ve Doğu bölgelerindeiki kırsal yerleşim biriminde ve İstanbul'da alt, orta ve üst sosyoekonomik statüde yer alan 1025 kişiyi içeren örneklemle 
araştırma yapmışlardır. Boylamsal, kesimsel karşılaştırmalara dayanan Çocuğun Değeri Araştırması, toplumdaki sosyoekonomik gelişmeye ve özellikle artan eğitime bağlı olarak çocukların ekonomik/yararcı değerinin azaldığını ve psikolojik değerinin arttığını bulmuştur. Araştırmacılar, kırsal, köy toplumunda her bir çocuğun ekonomik/yararcı değer bakımından parasal/maddi katkısı göz önüne alındığında daha çok çocuğun, daha çok yarar anlamına geldiğini ve günümüz kent toplumunda bir ya da iki çocuğun psikolojik değer bakımından annelerin-babaların gereksinim duyduğu tüm sevgiyi, sevinci ve diğer psikolojik doyumları getirdiğini ileri sürmüşlerdir. Araştırmacılara göre günümüz kent toplumundaki ailelerde azalan doğurganlık ve çocuk sayısının düşmesi,ailelerde çocukların ekonomik/yararcı değerlerinin azalması ve psikolojik değerlerinin artması anlamına gelmiştir. Türkiye'de eğitim ve endüstrileşmeye bağlı olarak gençlerin, annelerinden-babalarından bağımsız olma, ayrılma eğilimleri endüstri kent toplumunda çekirdek aileyi ortaya çıkarmakla birlikte bu değişim, modernleşme perspektifinin ileri sürdüğüayrılma ve bağımsızlık yönündeBatılı aile biçimindegerçekleşmemiş, bunun yerine ekonomik vemaddi alanda bağımsızlık ile duygusal alanda bağlılığ birleştiren, bütünleştiren farklı bir aile ilişkileri modeli kendini göstermiştir. $\mathrm{Bu}$ tür bir aile ilişkileri modeli, hem kırsal köy ve tarım toplumunda ataerkil geniş aile yapısında içerilenevlatlarınannelere-babalara olan ekonomik-maddi bağımlılığının azalmasıbakımındanhem geleneksel köy toplumundadüşük sosyoekonomik statüdeki aile örneğinde var olan evlatların annelere-babalara duygusal bağlılığı bakımındanBatılı orta sınıf aile örneğinden farklılaşmıştır. Geleneklerin yaygın olduğu kırsal, köy ve tarım toplumundaki ataerkil genişaile örneğindeanneler-babalar, evlatlarından ekonomik, maddi yararlar sağladığı ve yaşlılıkta yaşamlarını sürdürmek için evlatlarından bakım, yardım, destek beklediği için onlara bağımlı konumda iken anneler-babalar, ailedeki sosyalleştirilme süreçlerinde çocuklarının kendilerine itaat etmesini, uyum vesadakat göstermesini, aile ile ilişkilerini ve aileye bağlılıklarını sürdürmesini istemiş ve çocuklarını bu yönde sosyalleştirmeye çalışmıştır. Özerk çocuklar, ailelerinin gereksinimlerinden çok kendi gereksinimlerine bakma eğiliminde ayrı ve bağımsız genç yetişkinler olarak büyüdükleri için çocuklarda özerkliğin gelişimi istenmemiştir. Toplumdaki sosyoekonomik gelişme ve kentleşme, kuşaklar arasındaki ekonomik, maddi bağımlılıkları azaltmıştır. Çocuklar ailelerinegelir ve kazanç sağlayan bireyler olmaktan çok, aileler çocuklarına başta onların eğitimi gibi birçok alanda onlar için parasal harcama yapmış ve onların ekonomik masraflarını karşılamıştır. Günümüz kent yaşamında anneler-babalar,yaşlandıklarında kendilerine evlatlarının bakacağı yönünde bir beklentiyi sürdürmelerine karşın, onlar için seçenekler artmış, sosyal ve ekonomik güvence olarak toplumda yaşlılara hizmet veren kurumlardanyararlanabilme firsatları doğmuştur. Bir yandan kentin yaşam biçimi, okul başarısı ve uzmanlaşan işler, meslekler,çocuklarda ve ergenlerdeözerkliği geliştirmeyi gerektirirken ve aileler,hâlâ anneler-babalar ile evlatlar arasındaki duygusal ilişkileri, insani bağl1lıkları değerli görürken, diğer yandan günümüz kent yaşamının gerektirdiği bir değişme olarak sosyalleştirme ya da eğitim süreçlerinde çocuklardaki özerkliğin gelişimine daha çok yer verilmiştir(Kağıtçıbaşı ve Ataca, 2005). Diğer bir çalışmada araştırmacılar alt sosyoekonomik statüdeki annelerin 3 ile 5 yaşlar arasındaki çocuklarına ilgi ve etkileşim düzeyini incelemişler ve“yemek zamanı dışında ne kadar sıklıkta tam olarak çocuklarınızla ilgileniyorsunuz?" sorusuna annelerin \% 22 oranı "asla ya da hemen hemen hiç” diye cevap verirken, annelerin \% 40’tan daha çoğu, düşük düzeyde ilgi gösterdiğini söylemiştir. Araştırma aile stres modelinin savlarını destekleyen bulguları ortaya çıkarmıştır 
(Kağıtçıbaşı, Sunar ve Bekman, 2001; Kağıtçıbaş1, 1991, 1996). Anne-baba değerleri ile ilgili bir araştırmada ise altsosyoekonomik statüdeki anneler-babalarçocuklarından minnettarlık beklerken, orta ve üstsosyoekonomik statüdeki anneler-babalarçocuklarında özerkliğin gelişimine değer vermişler,onlardan minnettarlık beklemekle birlikte yakınlık göstermelerini istemişlerdir (İmamoğlu, 1987).

\section{Sonuç}

Yoksulluk ve ekonomik güçlük, sosyalleştirme süreçlerini ve çocukların ve ergenlerin bilişsel gelişimini, bilişsel becerilerini ya da okul başarısını etkilemektedir. Araştırma bulguları, ekonomik güçlük ile ilgili aile stres modelinin ileri sürdüğü savları desteklemekte, yoksulluğun ve ekonomik güçlüğün ekonomik baskıya yol açtığını veailelerde hissedilen ekonomik baskının annelerin-babaların moral bozukluğu, üzüntü, endişe, kızgınlık ve yabancılaşma gibi olumsuz duyguları yaşama olasılığını arttığını göstermektedir. Yoksulluk ve ekonomik güçlük, annelerin-babaların onların fiziksel, sosyal, psikolojik ve bilişsel gelişimine yararlı olmak ve katkı sağlamak amacıyla yaptıkları çocukları ile etkileşme ve onları sosyalleştirme çabalarını azaltmaktadır. Annelerin-babaların duygularını, davranışlarını ve ilişkilerini olumsuz olarak etkilemesi ve ailedeki sıcaklığı, duyarlılığı ve gözetimi azaltması ve annelerin-babaların çocuklarıyla ilişki ve etkileşimlerinde ilgi göstermeme,çatışma vetutarsız davranışlarını ve sert ceza kullanma eğilimlerini arttırması nedeniyle düşük gelir, yoksulluk ve ekonomik güçlük, ailenin işlevine, işlerliğine ve sosyalleştirme süreçlerine zarar vermektedir. Gelir düzeyi düşük, yoksul ve morali bozuk anneler-babalar, çocuklarına okuma, dil ve konuşma becerilerini öğretmek içinverimli, bol, zengin konuşma, ev ödevinde onlara yardım etme, çocuklarına bilişsel olarak teşvik eden öğrenme etkinlikleri düzenleme ve deneyimler kazandırma gibi uygulamalarla daha az meşgul olmaktadır. Araştırma bulguları, gelir düzeyi düşük, yoksul ve ekonomik güçlüğü yaşayan ailelerdeki çocukların düşük zeka puanları, düşük bilişsel beceriler, düşük eğitimsel kazanım, düşük okul başarısı gibi olumsuz sonuçlara sahip olma riskinin yüksek olduğunu göstermektedir.

\section{Kaynakça}

Anand, P., Lea, S. (2011). "The Psychology and Behavioural Economics of Poverty”, Journal of Economic Psychology, 32: 284-293.

Baker, C. E., Cameron, C. E., Rimm-Kaufman, S. E., Grissmer, D. (2012). "Family and Sociodemographic Predictors of School Readiness Among African American Boys in Kindergarten", Early Education and Development, 23: 833-854. 
Bradley, R. H., Corwyn, R. F. (2002). “Socioeconomic Status and Child Development”, Annual Review of Psychology, 53: 371-399.

Burchinal, M., Vernon-Feagans, L., Cox, M., Investigators, K. F. L. P. (2008). "Cumulative Social Risk, Parenting and Infant Development in Low-Income Rual Communities", Parenting. Science and Practice, 8: 41-69.

Burney, V. H., Beilke, J. R. (2008). "The Constraints of Poverty on High Achievement", Journal for the Education of the Gifted, 31: 295-321.

Collins, W. A., Maccoby, E. E., Steinberg, L., Hetherington, E. M., Bornstein, M. H. (2000). "Contemporary Research on Parenting: The Case of Nature and Nurture", American Psychologist, 55: 218-232.

Conger, R. D. Conger, K. J. Elder, G. H., Jr., Lorenz, F. O., Simons, R. L., Whitbeck, L. B. (1992). "A Family Process Model of Economic Hardship and Adjustment of Early Adolescent Boys”, Child Development, 63: 526-541.

Conger, R. D., Conger, K. J., Elder, G. H., Jr., Lorenz, F. O., Simons, R. L., Whitbeck, L. B. (1993). "Family Economic Stress and Adjustment of Early Adolescent Girls", Child Developmental Psychology, 29: 206-219.

Conger, R. D., Conger, K. J. (2002). "Resilience in Midwestern Families: Selected Findings From the First Decade of A Prospective, Longitudinal Study", Journal of Marriage and Family, 64: 361-373.

Conger, R. D., Wallace, L. E., Sun, Y., Simons, R. L., McLoyd, V. C., Brody, G. (2002). "Economic Pressure in African American Families: A Replication and Extension of Family Stress Model”, Developmental Psychology, 38: 179-193.

Conger, R. D. (2005). The Effects of Poverty and Economic Hardship Across Generations. Center for Public Policy Research, University of California, Davis.

Conger, R. D. ve Dogan, S. J. (2007). "Social Class and Socialization in Families", In Handbook of Socialization: Theory and Research (pp. 433-456). (Eds: Joan E. Grusec ve Paul D. Hastings), New York London: The Guilford Press.

Conger, R. D., Donnellan, M.B. (2007). “An Interactionist Perspective on The Socioeconomic Context of Human Development”, Annual Review of Psychology, 58: 175-199.

Costello, E. J., Compton, S. N., Keeler, G., Angold, A. (2003). "Relationships Between Poverty and Psychopathology: A Natural Experiment", Journal of the American Medical Association, 290: 2023-2029.

Crosnoe, R., Cooper, C. E. (2010). “Economically Disadvantaged Children's Transitions into Elementary School: Linking Family Processes, School Contexts, and Educational Policy" American Education Research Journal, 47: 258-291. 
Dahl, G. B., \& Lochner, L. (2005). The impact of Family Income on Child Achievement (Working Paper No. 11279).Cambridge, MA: National Bureau of Economic Research.

Duncan, G., Brooks Gunn, J., Klebanov, P. (1994). "Economic Deprivation and Early Childhood Development", Child Development, 65(2): 296-318.

Duncan, G. J. ve Brooks-Gunn, J. (1997). Consequences of Growing Up Poor. New York: Russell Sage Foundation.

Duncan, L. G., Seymour, P. H. (2000). "Socio-economic Differences in Foundation-Level Literacy”, British Journal of Psychology, 91: 145-166.

Dyson, L. L., Hett, G., Blair, K. (2003). “The Effect of Neighborhood Poverty on School Achievement and Behavior: A Study of Children in a Low-Income Neighborhood School in Canada", Connections, 3: 191-199.

Elder, G. (1999) Children of The Great Depression: Social Change in Life Experience, Boulder, CO, Westview Press.

Entwisle, D., Alexander, K. (1993). "Entry into School: The Beginning School Transition and Educational Stratification in The United States" Annual Review of Sociology, 19(1): 401-423.

Gelfand, D. M., Teti, D. M. (1990). “The Effects of Maternal Depression on Children”, Clinical Psychology Review, 10(3): 329-353.

Gennetian, L. A., Miller, C. (2002). "Children and Welfare Reform: A View from An Experimental Welfare Program in Minnesota”, Child Development, 73: 601-620.

Guo, G., Harris, K. M. (2000). "The Mechanisms Mediating The Effects of Poverty on Children's Intellectual Development”, Demography, 37: 431-447.

Halle, T., Kurtz-Costes, B., Mahoney, J. (1997). "Family Influences on School Achievement in Low-Income, African American Children”, Journal of Educational Psychology, 89: 527-537.

Haveman, R., Wolfe, B. (1995). "The Determinants of Children's Attainments: A Review of Methods and Findings", Journal of Economic Literature, 33: 1829-1878.

Hoff, E., Laursen, B. ve Tardif, T. (2002). “Socioeconomic Status and Parenting”, In Handbook of Parenting: Volume 2: Biology and Ecology of Parenting (2nd ed., pp. 231-252). (Ed: March H. Bornstein), Mahwah, NJ: Erlbaum.

Hoffman, L. W. (2003). "Methodological Issues in The Studies of SES, Parenting, and Child Development" In Socioeconomic Status, Parenting, and Child Development (pp. 125-143). (Eds: March H. Bornstein ve Robert H. Bradley), Mahwah, NJ: Erlbaum.

Huston, A. C., Aronson, S. R. (2005). "Mothers' Time with Infant and Time in Employment As Predictors of Mother-Child Relationships and Children's Early Development", Child Development, 76: 467-482. 
İmamoğlu, E. O (1987). “An Interdependence Model of Human Development”, In Growth and Progress in Cross-Cultural Psychology (pp.138-145) (Ed: Çiğdem Kağıtçıbaşı), Lisse, The Netherlands: Swets ve Zeitlinger.

Kağıtçıbaşı, Ç. (1991). The Early Enrichment Project in Turkey. UNESCO-UNICEF-WFP Notes Comments... No. 193). Paris: UNESCO.

Kağıtçıbaşı, Ç. (1996). Family and Human Development Across Cultures: A View From The Other Side, Hillsdale, NJ: Lawrence-Erlbaum.

Kağıtçıbaşı, Ç. Sunar, D., Bekman, S. (2001). "Long-Term Effects of Early İntervention: Turkish Low-İncome Mothers and Children”, Applied Developmental Psychology, 22: 1-28.

Kağıtcıbaşı, Ç., Ataca, B. (2005). "Value of Children and Family Change: A Three-Decade Portrait From Turkey”, Applied Psychology: An International Review, 54 (3): 317-337.

Klebanov, P. K., Brooks-Gunn, J., McCarton, C., McCormick, M. C.. (1998). "The Contribution of Neighborhood and Family İncome to Developmental Test Scores Over The First Three Years of Life", Child Development, 69: 1420-1436.

Kohn, M. L. (1995). "Social Structure and Personality through Time and Space”,In Examining Lives in Context: Perspectives on The Ecology of Human Development (pp.141-168) (Eds: Phyllis Moen, Glenn H. Elder, Jr. ve Kurt Lüscher), Washington, DC: American Psychological Association Press.

Korenman, S., Miller, J. E., Sjaastad, J. E. (1995). "Long-Term Poverty and Child Development in The United States: Results From The NLSY”, Children and Youth Services Review, 17(1-2): 127-155.

Lareau, A. (2003). Unequal Childhoods: Class, Race, and Family Life, Berkeley, CA: University of California Press.

Lee, V. E. ve Burkam, D. T. (2002). Inequality at The Starting Gate: Social Background Differences in Achievement As Children Begin School, Washington, DC: Economic Policy.

Leventhal, T. ve Brooks-Gunn, J. (2003). "Moving on Up: Neighborhood Effects on Children and Families", In Socioeconomic Status, Parenting and Child Development (pp. 209-230) (Eds: March H. Bornstein ve Robert H. Bradley), Mahwah, NJ: Erlbaum.

Lovejoy, M. C., Graczyk, P. A., O'Hare, E., Neuman, G. (2000). "Maternal Depression and Parenting Behavior: A Meta-Analytic Review”, Clinical Psychology Review, 20(5): 561-592.

Luster, T., Rhoades, K. ve Haas, B. (1989). "The Relation Between Parental Values and Parenting Behavior: A Test of The Kohn Hypothesis", Journal of Marriage and the Family, 51: 139-147.

Mayer, S. (1997). What Money Can't Buy: Family Income and Children's Life Chances, Cambridge, MA: Harvard University Press. 
McLoyd, V. C. (1990). "The İmpact of Economic Hardship on Black Families and Children: Psychological Distress, Parenting, and Socioemotional Development”, Child Development, 61: 311-346.

McLoyd, V. C. (1998). "Socioeconomic Disadvantage and Child Development", American Psychologist, 53(2): 185-204.

Menaghan, E. G., Parcel, T. L. (1991). "Social Sources of Change in Children's Home Environments: The Effects of Parental Occupational Experiences and Family Conditions", Journal of Marriage and the Family, 57: 69-94.

Mistry, R. S., Vandewater, E. A., Huston, A. C., McLoyd, V. C. (2002). "Economic Well-Being and Children's Social Adjustment: The Role of Family Process in an Etnically Diverse LowIncome Sample" Child Development, 73: 935-951.

Parke, R. D., Coltrane, S., Duffy, S., Buriel, R., Dennis, J., Powers, J., French, S., Widaman, K. F. (2004). "Economic Stress, Parenting, and Child Adjustment in Mexican American and European American Families", Child Development, 75(6): 1632-1656.

Reardon, S. F. (2013). “The Widening Income Achievement Gap”, Educational Leadership, 70(8): 10-16.

Sameroff, A. J., Seifer, R., Barocas, R., Zax, M., Greenspan, S. (1987). “Intelligence Quotient Scores of 4-Year-Old Children: Social-Environmental Risk Factors”, Pediatrics, 79(3): 343350.

Sameroff, A. J., Seifer, R., Baldwin, A., Baldwin, C. (1993). "Stability of Intelligence From Preschool to Adolescence: The Influence of Social and Family Risk Factors", Child Development, 64(1), 80-97.

Sampson, R., Sharkey, P., Raudenbush, S. W. (2008). "Durable Effects of Concentrated Disadvantage on Verbal Ability Among African- American Children", Proceedings of the National Academy of Sciences, 105: 845-852.

Senechal, M., LeFevre, J. (2002). "Parental Involvement in The Development of Children's Reading Skill: A Five-Year Longitudinal Study”, Child Development, 73: 445-460.

Smith, J. R., Brooks-Gunn, J. ve Klebanov, P. K. (1997). "Consequences of Living in Poverty For Young Children's Cognitive and Verbal Ability and Early School Achievement", In Consequences of Growing Up Poor (pp. 132-189) (Eds: Greg J. Duncan ve Jeanne BrooksGunn), New York: Russell Sage Foundation.

Solantaus, T., Leinonen, J., Punamaki, R. L. (2004). “Children's Mental Health in Times of Economic Recession: Replication and Extension of the Family Economic Stress Model in Finland", Developmental Psychology, 40: 412-429.

Strohschein, L. (2005). "Household Income Histories and Child Mental Health Trajectories", Journal of Health and Social Behavior, 46: 359-375. 
Şirin, S. R. (2005). "Socioeconomic Status and Academic Achievement: A Meta-Analytic Review of Research", Review of Educational Research, 75(3): 417-453.

Votruba-Drzal, E. (2003). “Income Changes and Cognitive Stimulation in Young Children's Home Learning Environment”, Journal of Marriage and Family, 65(2): 341-35.

Yeung, W. J., Linver, M. R., Brooks-Gunn, J. (2002). "How Money Matters For Young Children's Development: Parental Investment and Family Processes" Child Development, 73(6): 1861-1879. 